\section{Danube Commission}

\section{Rash of riparian rows}

THE Austrian government has given in to ecological pressure and the Czechoslovak government by halting the clearing of land for the proposed Hainberg hydroelectric dam in the Au forest. The Czechoslovak government has for some time been complaining that the dam, on the Danube, would lower the water table and cause considerable economic and ecological damage downstream. But the dam is only the latest of a series of squabbles about the proper use of the Danube.

Only last week, Belgrade radio was complaining that, during the present cold spell in Central Europe, Romania has been "appropriating" some 5 million kilowatts of hydroelectric capacity from the Danube, decreasing the water level by 2 metres and forcing the Yugoslav power station at Kostolac to close down. And last November, shipping on the Danube was brought to a halt when Romania closed the locks of the Iron Gates for maintenance, giving only a few days' notice rather than the minimum of two months required by the 1984 Danube Convention.

The deficiencies of the convention, and of the International Danube Commission which administers it, are thus being exposed. Part of the trouble is that the convention is concerned only with navigation on the Danube. The original members of the convention were the riparian countries from Czechoslovakia downstream, with the Soviet Union represented twice (as the USSR and the Ukrainian SSR). Austria acceded in 1960 but there has never been a serious suggestion that West Germany should sign, since the river is not commercially navigable until it reaches Austria.

Although the Danube Commission's competence has been extended to include, for example, pollution due to shipping and the regulation of barges carrying hazardous chemicals, it has no mandate to deal with other sources of pollution.

In the dispute over the Hainberg dam, both Austria and Czechoslovakia have been able to claim that they have been acting in accordance with the commission's ruling. Austria, for example, has said that it is carrying out the commission's resolution that all member states should accelerate development of the Danube waterway by building dams which, to be cost-effective, must be hydroelectric stations. (Austria has renounced the nuclear option, and so also needs the electricity.) Czechoslovakia, on the other hand, says that Austria's "unilateral", decision to build a dam at Hainberg "violates the tried and trusted concept of the comprehensive use of the Danube", developed by the commission. Both governments claim ecological support - the Austrians that the dam would prevent upstream deepening of the Danube channel and the consequent desiccation of important wetlands, Czechoslovakia that the downstream channel would be deepened.

Ironically, the Czechoslovak argument that the water table would be lowered is reminiscent of that advanced by Hungarian ecologists against the joint Czechoslovak/Hungarian project to build two dams on the Danube, at Gabcikovo in Slovakia and Nagymaros in Hungary. The second of these, which would drown the scenic "Danube bend"' above Budapest, has been suspended since 1981 , ostensibly for lack of funds. But the Czechoslovak side has forged ahead at Gabcikovo, ignoring the claim of the Hungarian ecologists that the water table in northern Hungary would be lowered. Especially because Gabcikovo would divert the main navigation channel away from the Hungarian frontier into Slovak territory, it is clearly a matter within the competence of the Danube Commission.

The commission has nevertheless been strangely silent, perhaps because, from its seat in Budapest, it is reluctant to embarrass its Hungarian hosts. In the past few days, however, the commission has been able to set up a joint Czechoslovak/ Austrian team of experts to assess the ecological consequences of the Hainberg scheme, while the Austrian Chancellor, $\mathrm{Mr}$ Fred Sinowatz, is said to have promised to pay more attention to ecological matters in future.

The Danube Commission has thus been spared embarrassment for the time being, but if it is to retain its credibility for competence and effectiveness, some rethinking of its role seems an urgent need.

Vera Rich

\title{
There's no place like home
}

\section{Washington}

A US APPEALS court, overruling the Internal Revenue Service (IRS), has allowed a university professor to deduct from his income tax the cost of maintaining an office in his home. The ruling is expected to relax significantly what had been a virtual prohibition by IRS against such deductions by faculty members.

Tax rules allow employees to claim a deduction for an office in the home if three conditions are met: the office must be used exclusively for business and on a regular basis, it must be the employee's "principal place of business" and it must be maintained for the "convenience of the employers". It was the last two points that were in contention in the appeals-court case, which was brought by David Weissman, a philosophy professor at the City College of New York.

In ruling in Weissman's favour, the court explicitly found that a professor's duties include research. Weissman said he spent 80 per cent of his working hours at home, doing scholarly research. IRS argued before the court that most of Weissman's research had nothing to do with his job, but was merely to "increase his own prestige" and to secure "a more lucrative position". IRS had prevailed with that argument in the lower US Tax Court, which sided with IRS in a decision last year.

The appeals court, however, noted that City College by-laws require promotions of faculty members to be based in part upon a professor's “'record of significant scholarly achievement". And it agreed with Weissman that his principal place of business was in fact his home. The court cited its own earlier finding that a group of musicians who performed at Lincoln Center in New York City were entitled to deduct the expense of maintaining practice space in their homes: "A college professor's principal place of business is not necessarily the college at which he teaches any more than a musician's principal place of business is necessarily the concert hall in which he performs".

Many faculty members were able to claim home-office expenses on their tax returns before 1976, when Congress tightened the requirements; under the old rules, if such an office was "appropriate and helpful" to an employer, it qualified. The new ruling does not turn back the clock that far and may not be applicable to other professors who want to claim similar deductions.

For one thing, under the peculiar rules that apply to the tax-court system, the court's decision sets a precedent only in the circuit covered by this one appeals court, which includes New York, Connecticut and Vermont. The lower Tax Court's decision, though overturned in this one circuit, is still the law in the rest of the country. IRS would thus be within its rights to continue disallowing similar claims from professors in most of the country. In addition, a successful claim may have to show that the university did not provide adequate office space, making a home office a virtual necessity. The appeals court seemed to be impressed by the fact that Weissman's office at City College was shared with several other faculty members, had no typewriter and was the target of frequent break-ins and vandalism, making it unsafe for storing research material or office equipment.

The City College Professional Staff Congress, the faculty union, hailed the rulng as a "victory" that "clearly states that a faculty member's responsibility involves more than teaching and classroom responsibilities'”. Stephen Budiansky 